\title{
The impact of manufacturing industries on Ghana's economy
}

Addo, Eric Osei $\<$

Beijing Normal University, China (ericoseiaddo@hotmail.com)

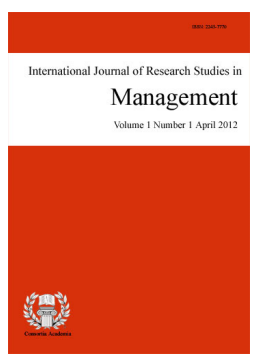

Accepted: 16 November 2017

ISSN: 2243-7770 Online ISSN: 2243-7789

OPEN ACCESS

\section{Abstract}

Ghana's economic growth over the last decade has been among the most rapid in Africa and faster than in some high investment emerging market economies. The economy of Ghana has experienced moderate but consistent growth over the past 25 years, with growth rate between 1990 and 2010 averaging 5 percent. Industry in Ghana accounts for about 25.3\% of total GDP. However, Ghana's industrial production is rising at a $7.8 \%$ rate, giving it the 38th fastest growing industrial production in the world due to government industrialization policies. Currently, it is estimated that the average medium-term real GDP growth rate in Ghana would be at least $8 \%$ per annum. Currently, Ghana's industrial sector after the rebasing of the national account estimates in November 2010 consists of five sub-sectors namely; Manufacturing, Construction, Mining and Quarrying, Electricity, Water and Sewerage. Prior to the rebasing, the electricity and water and sewerage sub-sectors had been lumped together. The key objective of the study is to examine the factors that affect the competitiveness of local industries highlighting both the internal and external constraints. Questionnaires were used as the main instrument for primary data collection from the respondents. Also, various questions under each objective were analyzed systematically using the one sample t-test presented in tables and graphs (SPSS and Excel). In addition, Michael Porter's Theory was used to analyze the competitiveness of local manufacturing industries in Ghana. Lastly, logical inferences and interpretations were made out of the resultant data.

Keywords: competitiveness; manufacturing industries; Ghana 


\section{The impact of manufacturing industries on Ghana's economy}

\section{Introduction}

In 1957, after Ghana gained independence, the Nkrumah government launched an industrialization drive that increased manufacturing's share of GDP from 10 percent in 1960 to 14 percent in 1970. This expansion resulted in the creation of a relatively wide range of industrial enterprises, the largest including the Volta Aluminum Company (Valco) smelter, saw mills and timber processing plants, cocoa processing plants, breweries, cement manufacturing, oil refining, textile manufacturing operations, and vehicle assembly plants. Many of these enterprises, however, survived only through protection. The overvalued cedi, shortages of hard-currency for raw materials and spare parts, and poor management in the state sector led to stagnation from 1970 to 1977 and then to a decline from 1977 to 1982 .

Thereafter, the manufacturing sector never fully recovered, and performance remained weak into the 1990s. Underutilization of industrial capacity, which had been endemic since the 1960s, increased alarmingly in the 1970s, with average capacity utilization in large- and medium-scale factories falling to 21 percent in 1982. Once the Enterprise Resource Planning (ERP) began, the supply of foreign exchange for imported machinery and fuel substantially improved, and capacity utilization climbed steadily to about 40 percent in 1989 . Nevertheless, by 1987 production from the manufacturing sector was 35 percent lower than in 1975 and 26 percent lower than in 1980.

Ghana's record with industrialization projects since independence is exemplified by its experience with aluminum, the country's most conspicuous effort to promote capital-intensive industry. This venture began in the mid-1960s with the construction of a 1,186-megawatt hydroelectric dam on the lower Volta River at Akosombo. The Akosombo Dam was the centerpiece of the Volta River Project (VRP), which the Nkrumah government envisioned as the key to developing an integrated aluminum industry based on the exploitation of Ghana's vast bauxite reserves and its hydroelectric potential. Valco became the principal consumer of VRP hydroelectricity, using 60 percent of VRP-generated power and producing up to 200,000 tons of aluminum annually during the 1970 s.

Changing global economic conditions and severe drought dramatically affected the Ghanaian aluminum industry during the 1980s. The discovery of vast bauxite reserves in Australia and Brazil created a global oversupply of the mineral and induced a prolonged recession in the aluminum trade. Under these conditions, Valco found it far more economical to import semi-processed alumina from Jamaica and South Korea than to rely on local supplies, despite the discovery in the early 1970s of sizable new deposits at Kibi. Valco's refusal to build an aluminum production facility brought Kaiser and Reynolds into bitter conflict with the government.

Severe drought compounded the effects of unfavorable market conditions by reducing the electricity generating capacity of the Akosombo Dam and by forcing a temporary shutdown of the smelter from 1983 to 1985. Aluminum production was slow to recover in the wake of the shutdown. In the early 1990s, aluminum production and exports continued to be negligible. Drastic currency devaluation after 1983 made it exceptionally expensive to purchase inputs, which hurt businessmen in the manufacturing sector. Furthermore, the ERP's tight monetary policies created liquidity crises for manufacturers, while liberalization of trade meant that some enterprises could not compete with cheaper imports. These policies hurt industries beset by long recession, hyperinflation, outmoded equipment, weak demand, and requirements that they pay 100 percent advances for their own inputs. Local press reports have estimated the closure of at least 120 factories since 1988, mainly because of competitive imports. The garment, leather, electrical, electronics, and pharmaceuticals sectors had been particularly hard hit. In 1990, even the New Match Company, the only safety match company in the country, closed. 
ERP strategies made it difficult for the government to assist local enterprises. Committed to privatization and the rule of free market forces, the government was constrained from offering direct assistance or even from moderating some policies that had a detrimental impact on local manufacturers. Nevertheless, the Rawlings government initiated programs to promote local manufacturing. In 1986, the government established the Ghana Investment Center to assist in creating new enterprises. Between 1986 and 1990, the vast majority of projects approved 444 of 621 were in the manufacturing sector. Projected investment for the approved ventures was estimated at US\$138 million in 1989 and at US\$136 million in 1990. In the initial phase, timber was the leading sector, giving way in 1990 to chemicals. In 1991 the government established an office to deal with industrial distress in response to complaints that "unrestrained imports" of foreign products were undermining local enterprises. The 1992 budget included assistance for local industrialists; $\not 2$ billion was set aside as financial support for "deserving enterprises."

Ghana's most important manufacturing industries include electronics manufacturing, car manufacturing, electric car manufacturing, automotive manufacturing, light manufacturing, aluminum smelting, food processing, cement and small commercial ship building. A relatively small glass-making industry has also developed due to the high-quality sand available from the Tarkwa mining area. The foreign capital has increased in recent years. Most products are for local consumption and exportation. Other industries include the production of food and beverages, textiles, chemicals and pharmaceuticals, and the processing of metals and wood products. The development community has long upheld that a thriving private sector is essential for economic development. Local industries play an instrumental, but often under-recognized, role in private sector growth.

This report reviews a large body of research, and demonstrates how local industries in developing countries are often hampered by an inability to obtain financial capital for growth and expansion. Local financial institution (systems) does not sufficiently cater for the sector, with negative consequences for economic development. This report develops interventions to close the gap in financing, and outlines contributing roles for public and multilateral actors. It describes both the challenges and the potential for international financial institutions to work through local intermediaries and stimulate capital provision to Industries in a financially and socially sustainable manner. The "top three" issues that emerge from a current industrial policy debate relate to the key developmental objectives of the current industrial policy. These include:

$>$ How to empower the private sector, especially small and medium enterprises, to expand productive employment and technological capacity within a highly competitive manufacturing sector.

$>$ How to promote agro-based industrial development to ensure value-addition to manufactures and Ghana's traditional and non-traditional exports; and

$>$ How to promote the spatial distribution of industries away from the current situation of over-concentration of industries within urban areas.

In addition, Internal Factors such as management skills, capital, level of education and external relation management whilst the External Factors namely competitiveness includes, electricity supply, tax system, rent cost and consumer preference affecting local industries. It was recommended that government should create enabling business environments which will foster economic growth and sustainability; owner-managers should update their skills regularly to meet changing consumer preference and finally owner-managers should bring on board people with the necessary skills to expand their business.

Lastly, below two primary approaches to industrial policy were to be considered -

D Horizontal policies aimed at correcting market failures that affect the broader economy. These are policies intended to improve the overall performance of the economy and the business environment within which firms operate. Horizontal policies are generally considered to be market-friendly. They favour promoting research and development $(R \& D)$, improving education and infrastructure which 
benefit everyone, protecting property rights etc. In that regard, most of the economic reforms that many developing countries, especially African countries, have pursued under structural adjustment programmes and more, can be argued to have been intended to achieve the expected outcomes of a horizontal industrial policy.

$>\quad$ Vertical or sectoral policies are aimed at enhancing certain sectors, new or existing ones. These policies include providing subsidies or other fiscal incentives for select sectors, attracting foreign direct investment to targeted sectors and sometimes directed production of key products by state-owned enterprises.

Table 1

Industry and Sub-Sectors Share of GDP, 2006-2012

\begin{tabular}{|c|c|c|c|c|c|c|}
\hline \multirow{2}{*}{ YEAR } & \multirow{2}{*}{$\begin{array}{c}\text { Industry } \\
\text { (\% of } \\
\text { GDP) }\end{array}$} & \multicolumn{5}{|c|}{ Share of Industrial Sub-Sectors of GDP (\%) } \\
\hline & & Manufacturing & Mining \& Quarrying ${ }^{++}$ & Electricity & Water \& Sewerage & Construction \\
\hline 2006 & 20.8 & 10.2 & $2.8(0.0)$ & 0.8 & 1.3 & 5.7 \\
\hline 2007 & 20.7 & 9.1 & $2.8(0.0)$ & 0.6 & 1.0 & 7.2 \\
\hline 2008 & 20.4 & 7.9 & $2.4(0.0)$ & 0.6 & 0.8 & 8.7 \\
\hline 2009 & 19.0 & 6.9 & $2.1(0.0)$ & 0.5 & 0.7 & 8.8 \\
\hline 2010 & 19.1 & 6.8 & $2.3(0.4)$ & 0.6 & 0.8 & 8.5 \\
\hline 2011 & 25.9 & 6.7 & $8.5(6.8)$ & 0.6 & 0.8 & 9.2 \\
\hline 2012 & 27.6 & 6.7 & $8.8(6.9)$ & 0.5 & 0.7 & 10.9 \\
\hline
\end{tabular}

Note.++ means $=$ crude oil.

Source. Ghana Statistical Service, National Accounts Statistics.

Table 2

Contribution of Manufacturing Sector to GDP (2006 - 2014)

\begin{tabular}{cccccccccc}
\hline YEAR & 2006 & 2007 & 2008 & 2009 & 2010 & 2011 & 2012 & 2013 & 2014 \\
\hline GDP $(\%)$ & 10.2 & 9.1 & 7.9 & 6.9 & 6.8 & 6.7 & 6.7 & 5.8 & 5.5 \\
\hline
\end{tabular}

Source. Ghana Statistical Service, National Accounts Statistics.

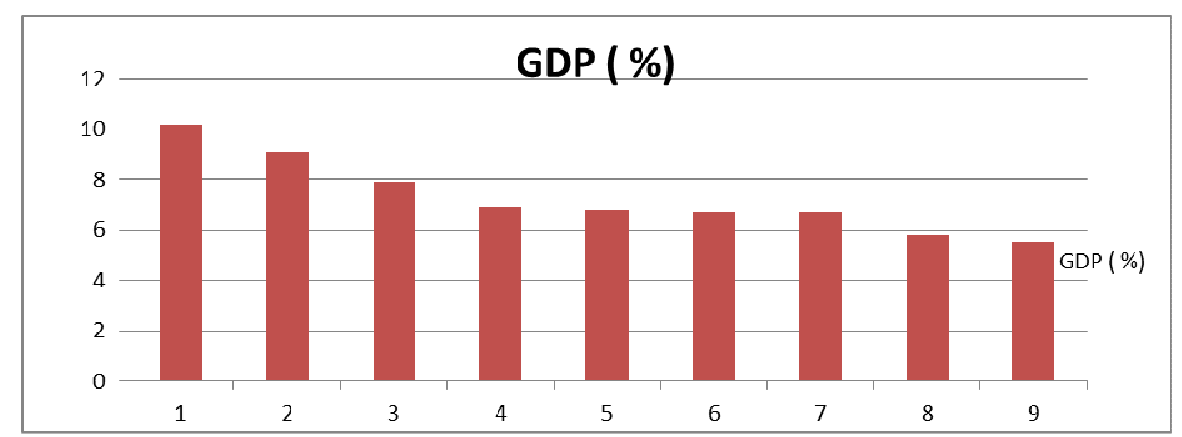

Figure 1. Contribution of Manufacturing Sector to GDP (2006 - 2014

Source. Ghana Statistical Service, National Accounts Statistics.

The dominant trends in manufacturing, nonetheless, were the involvement of foreign capital and the initiation of joint ventures. Significant new enterprises included a US\$8 million Taiwanese-owned factory, capable of turning out ten tons of iron and steel products per hour, which began trials at Tema in 1989. Although approximately 500 projects had been approved since the investment code came into force in 1985, almost half had still not been launched by the end of 1989. Between 90 and 95 percent of the approved projects were joint ventures between foreign and local partners, 80 percent of which were in the wood industry. Restructuring of the sector was proceeding through divestiture, import liberalization, and promotion of small-scale industries.

This research seeks, in other ways, to examine the factors that affect the competitiveness of local industries 
highlighting both the internal and external constraints.

\subsection{Research Problem}

Ghanaian industries have been plagued by a myriad of setbacks from both the external and internal environment affecting their competiveness in the local market. Many hardly survive after 5 years of operations and those which continue in business remain stagnant and unable to expand into other markets. Poor legal and regulatory environment, lack of access to risk capital and high cost of borrowing, inadequate education and lack of managerial skills have forestall its ability to expand and thus limiting their opportunities in the local market. The infiltration of foreigners into the Ghanaian market has made it even more difficult for Ghana industries to compete in the market. This study therefore seeks to analyze the factors influencing the competiveness of local industries in Ghana and explores the extent to which their success or failure depends on the wider business climate. This study also examines different internal factors that may be responsible for the unstable and limited growth.

\subsection{Research objectives}

The study seeks to achieve the following objectives:

To determine the internal factors affecting the competitiveness of local industries.

To identify the external factors affecting the competitiveness of local industries.

$>$ To ascertain the competitive strategies.

$>$ To explore ways of enhancing the competitiveness of local industries.

\subsection{Research Questions}

$>\mathrm{H}_{\mathrm{o}} \mathrm{a}$ - Internal factors affecting the competitiveness of the manufacturing industries?

$>$ H1a- Internal factors that do not affect the competitiveness of the manufacturing industries?

$>\mathrm{H}_{\mathrm{o}} \mathrm{b}$ - External factors affecting the competitiveness of the manufacturing industries?

$>$ H1b- External factors do not affect the competitiveness of the manufacturing industries?

$>\quad \mathrm{H}_{0} \mathrm{c}$ - Competitive strategies adopted by the manufacturing industries affecting their competitiveness?

$>$ H1c- Competitive strategies adopted by manufacturing industries that do not affect their competitiveness?

$>\quad \mathrm{H}_{\mathrm{o}} \mathrm{d}$ - The following measures like (Equal Playing Field) enhances the competitiveness of manufacturing industries?

$>$ H1d- The following measures like (Equal Playing Field) do not enhance the competitiveness of manufacturing industries? 
Addo, E. O.

\subsection{Significance of the Study}

The study will give a wider understanding about the factors which influence their competitiveness and enable stakeholders develop and implement policies which will foster the Ghana's economic growth. The findings of the study will also provide a readily accessible data for potential entrepreneurs to have a head start into running their own business and also existing local industries to enhance their business operations. The study will, lastly, be a valuable source of literature for students and individuals who may want to research the concept from other viewpoints.

\subsection{Scope and Limitation of the Study}

This study is focused on examining the factors that influence the competiveness of manufacturing industries, numbering some few companies in Accra (Greater Accra Region). Accra was chosen as a case study due to the large number of trading establishments in the area and also convenience in data collection.

\section{Literature review}

\subsection{Definitions of Manufacturing Industries}

Manufacturing industries refers to those industries involve in the manufacturing and processing of items and indulge in either creation of new commodities or in value addition. The manufacturing industry accounts for a significant share of the industrial sector in both developed and developing countries. The final products can either serves as a finished good for sale to customers or as intermediate goods used in the production process. Bartlesman and Gray (1996) define the concept as a branch of manufacture and trade based on the fabrication, processing, or preparation of products from raw materials and commodities. While, according to German Economist Alfred Weber (1909) a manufacturing industry can be seen as an industrial production, in which raw materials are transformed into finished goods on a large scale. Lastly, the National Association of Manufacturing (USA) defined the concept as businesses involve in manufacturing and processing of products.

\subsection{The Definition of Manufacturing Industries in Ghana}

Kayanula and Quartey (2000) define manufacturing as the process of converting raw materials into finished goods. The Ghana Statistical Service (GSS) in its industry survey defined the concept as a variety of activities involved in the production of goods and services. The Ghana Enterprise Development Commission (GEDC) defined manufacturing industries in terms of its plant and machinery. Kayanula and Quartey (2000) have raised the danger inherent in valuing a fixed asset and the effect of inflation on valuation, especially adopting the fixed assets criteria. The regional project on Enterprise Development Ghana manufacturing survey paper gave a definition to the sector industry classifying firms into micro enterprise (less than 5 employees), small enterprise (5 -29 employees), medium enterprise (30 - 99 employees) and large enterprise (100 and more employees).

\subsection{Competitiveness}

Li, Hitt, and Zhang (2011) cited Stigler (1991) who defines competition as "a rivalry between individuals and it arises whenever two or more parties strive for something that all cannot obtain". Scholars also stated that competition comprises four dimensions: competitors, competing objects, competitive capability and competed results. Competitiveness is the means by which entrepreneurs can improve their firms' performance (Ajitabh \& Momaya, 2003) which can be measured according to a number of dimensions including market share, profit, growth and duration. Man and Chan (2002) further stress the importance of links between competitiveness and performance as having a long-term rather than a short-term orientation. 


\subsection{Michael Porter's five forces of competitiveness (Porter, 1979) - Model}

Arguably, the most adopted theory for understanding competitive advantage is Michael Porter's competitive forces model. It is a simple framework for assessing and evaluating the competitive strength and position of a business organization namely threat of new entrants, threat of substitutes, bargaining power of customers, and bargaining power of suppliers and rivalry of competitors. This theory is based on the concept that there are five forces that determine the competitive intensity and attractiveness of a market. Porter's five forces help to identify where power lies in a business situation. This is useful both in understanding the strength of an organization's current competitive position, and the strength of a position that an organization may look to move into (Chartered Global Management Accountants, CGMA, 2015).

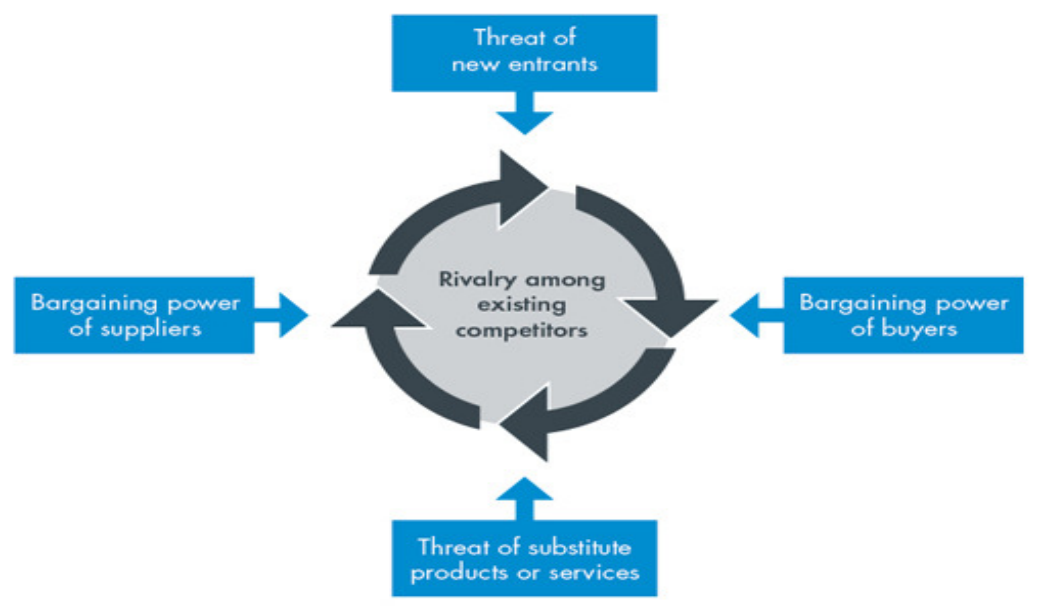

Figure 2. Michael Porter's Five Forces of Competitiveness

Source. CGMA, 2015.

Competitive Rivalry - This force examines how intense the competition currently is in the marketplace, which is determined by the number of existing competitors and what each is capable of doing. Rivalry competition is high when there are just a few businesses equally selling a product or service, when the industry is growing and when consumers can easily switch to a competitors offering for little cost. When rivalry competition is high, advertising and price wars can ensue, which can hurt a business's bottom line. Rivalry is quantitatively measured by the Concentration Ratio (CR), which is the percentage of market share owned by the four largest firms in an industry.

Bargaining Power of Suppliers - This force analyses how much power a business's supplier has and how much control it has over the potential to raise its prices, which, in turn, would lower a business's profitability. In addition, it looks at the number of suppliers available: The fewer there are the more power they have. Businesses are in a better position when there are a multitude of suppliers. Sources of supplier power also include the switching costs of firms in the industry, the presence of available substitutes, and the supply purchase cost relative to substitutes.

Bargaining Power of Customers - This force looks at the power of the consumer to affect pricing and quality. Consumers have power when there aren't many of them, but lots of sellers, as well as when it is easy to switch from one business's products or services to another. Buying power is low when consumers purchase products in small amounts and the seller's product are very different from any of its competitors.

Threat of New Entrants - This force examines how easy or difficult it is for competitors to join the marketplace in the industry being examined. The easier it is for a competitor to join the marketplace, the greater the risk of a business's market share being depleted. Barriers to entry include absolute cost advantages, access to inputs, economies of scale and well-recognized brands. 
Addo, E. O.

Threat of Substitute Products or Services - This force studies how easy it is for consumers to switch from a business's product or service to that of a competitor. It looks at how many competitors there are, how their prices and quality compare to the business being examined and how much of a profit those competitors are earning, which would determine if they have the ability to lower their costs even more. The threat of substitutes is informed by switching costs, both immediate and long-term, as well as a buyer's inclination to change.

\subsection{Internal Factors and Industry Competitiveness}

Internal factors affecting the competiveness of manufacturing industries in Africa are numerous. The following are some common ones noted by scholars and entrepreneurs.

Inadequate Financial Resources - Traditionally owner-managers depend on the savings, families and friends to access capital to run their business according to both (Osamwonyi, \& Tafamel, 2010). Moreover, owner-managers under no pressure to increase turnover and profits also preclude firms from having a large capital base. Because capital is central to all aspects of competiveness, manufacturing companies are not able to sustain their operations over a long period of time. For instance, recruitment of skilled employees, innovation, research, expansion among other are to some extent dependent on the capital base of the company.

Managerial skills - Human resource capabilities are one of the core competences every industry must possess to be able to remain competitive in this dynamic business environment (Lee, 2001; Batra \& Tan, 2003). Staw (1991) asserts that experience is the best predictor of business success, especially when the new business is related to earlier business experiences. When the owner-managers of such companies are educated they are more likely to hire skilled and educated employees to help run the business, and thus are more likely to be successful (Hewitt \& Wield, 1992). Owners need to acquire business management skills including marketing, financial management, leadership skills to be able to compete with rivalry firms. Perry and Pendleton, (1983) have observed that lack of these core competences have caused $90 \%$ of sector companies survival.

Education - Like special skills needed in a given trade, education in general equips owners with some requite skills to manage their business. Owners in Africa lack the needed education to thrive in the competitiveness of the industrial sector (Osamwonyi, \& Tafamel, 2010). King and McGrath (2002) noted that those with more education and training are more likely to be successful in the sector. Though Minniti and Bygrave (2003) have stated that people with more education are not necessarily more entrepreneurial than their uneducated counterparts, many studies shows that educated people are more successful in entrepreneurship (Meng \& Liang 1996; Staw, 1991; Holt, 1992; Lussiers \& Pfeifer, 2001; Minniti \& Bygrave, 2003).

Access to technology - Manufacturing companies struggle with meeting technological requirement to enhance their competiveness in many developing countries. They find it hard to employ specialists who possess the kills to manage this technology and often do not have enough funds to purchase the technology needed to remain competitive, due to their size. International Trade Corporation (2014) has observed that in developing countries, simple information and communications technology (ICT) solutions, such as access to the internet or the creation of a business website, often represent a significant challenge for the sector (McCormick \& Maalu, 2011; Chatterjee, Grewal, \& Sambamurthy, 2002).

Power sharing and control - Most owner-managers in Africa do not want to share ownership of their business with third parties, and doing everything from marketing, accounting to strategic management. Fletcher (2000) stated that $75 \%$ of manufacturing companies are owner-managed and therefore not under pressure from shareholders to increase profit and turnover. They would rather pass the ownership and control of the business to their son or other relatives, who often than not lacks the entrepreneurial spirit and drive to manage the company well (Kayanula \& Quartey 2000; Osamwonyi, \& Tafamel, 2010). Nzelibe (1996) further observed that the corporate structure and culture of a business reflects the founder's personality, as such certain traits cannot be passed from one to another. 
Strategic planning problems - According to Liedholm, MacPherson and Chuta (1994), Strategic planning and implementation is often needed in modern day business environment to thrive. Business management now has become dynamic and complex as consumers are now sophisticated and more informed than ever. Local companies often do not carry out proper strategic planning in their operations (Osamwonyi, \& Tafamel, 2010). Ojiako (1987) stated that one problem of such companies is lack of strategic planning. Sound planning is a necessary input to a sound decision-making. Often linked with the owner's level of education and based on proper record keeping, formulating, evaluating and implementing important strategies could be the deciding factor to stay ahead of competitors and gain larger market share (Man \& Chan, 2002; Chiloane-Tsoka \& Boya, 2014).

\subsection{External Factors and industry Competitiveness}

Factors shaping the competitiveness of manufacturing industries are not limited to that which the other company has control over, but also as Morrison (2006) noted external factors which the owner-managers have little or no control over. There following are some external factors influencing their success.

Access to finance - Access to finance is a major hurdle for their competitiveness in Africa. Initial capital needed to start business and even working capital support to expand business is difficult and / or expensive to get from banks in Africa (Mensah, 2004). Banks perceive manufacturing companies as a dynamic, complex and high risk sector to grants loans to (Beck, Demiurgic-Kunt, \& Levine, 2003). Venture capitalists and development banks on the other hand can hardly be found in Ghana making it difficult for such companies to access risk capital to invest in their business. Microfinance institutions have been supporting the sector industry initiative but the demand for collateral and high interest for loans among others hampers owner-managers to access loans for expansion (Osamwonyi \& Tafamel, 2010; International Finance Corporation [IFC], 2010; Bouazza, 2015).

Legal and regulatory environment - In the legal environment, "specifically, the affordability and consistency of the court system, enforcement capacity and the confidence in the legal system" strongly affect business growth (UNDP, 2012). The recent judges scandal that rocked Ghana championed by ace investigative journalist Anas Aremeyaw Anas has serious dented the image of the judicial system. Ghana's ranking in the Transparency International's Corruption Perceptions Index (CPI) in recent times to hasn't been encouraging at all, ranking $2^{\text {nd }}$ in Africa (Ghana News Agency, GNA, 2015; www.GraphicOnline.com). The weak legal system coupled with hidden charges and lengthy bureaucratic process has significantly affected the growth of manufacturing industries in Ghana.

Dynamic business environment - Global production is increasingly characterized by rapid changes in technology and by the need to adjust to changes in consumer demand. Access to a skilled workforce is crucial in such an environment, as skilled workers find it easier to adapt to changes in the working environment (Jansen \& Lanz, 2013). For instance, the spread of consumer awareness of sustainable development and environmentally friendly products force firms to adjust their business operations. Cheah and Chew (2005) argue that it is an opportunity for manufacturing industries to incorporate sustainability policies in their business strategies and operational activities, though there is a need for more institutional support and governmental encouragement to promote the benefits.

Government support - Government policies are another factor that influences the competitiveness of the sector industries in Ghana (Mensah, 2004). The idea of promotion has been in existence since 1970 though very little was done at the time. Key institutions have been set up to assist manufacturing companies and prominent among them is the Office of Business Promotion, the present Ghana Enterprise Development Commission (GEDC). GEDC was set up to assist Ghanaian entrepreneurs to enter into fields where foreigners mainly operated, and also had packages for strengthening small scale industry in general, both technically and financially enterprises (Abor \& Quartey, 2010). Though a lot have been put in place to help the sector to thrive, it looks like that has not been enough to create a more conducive environment for manufacturing companies to 
Addo, E. O.

grow (Kayanula \& Quartey, 2000; Harvie \& Lee, 2005; Frempong \& Essegbey, 2006).

Infrastructure - Ukpong and Iniodu (1991) are of the view that the infrastructure in some African countries forestalls the growth of manufacturing companies, in many senses. In order for the sector to thrive, the government needs to provide some basic infrastructure without which the production process and distribution chain come to a halt (Hulten, 2009; Bokea, Dondo, \& Mutiso, 1999). Infrastructure like internet, electricity, road, water among others is very expensive in some African countries, and even non-existent in other jurisdiction. For example reliable power supply is a major challenge in Nigeria and Ghana, with the latter's recent electrical power crises having crippled many manufacturing companies and consequently mass layoffs. Manufacturing companies would have to acquire alternative power at a higher cost to produce their goods and thus putting them at disadvantage in competing with foreign companies.

Trade costs - High cost of operation is another form of barrier, in terms of rent, exchange rate, interest rate, inflation, taxation etc. Rent for instance is a very high fixed cost for many traders in Ghana and Nigeria. Store owners demand several years rent in advance for the stores, eroding manufacturing companies' profits. This development has either slowed the growth of companies or forced many out of business. Temtime and Pansiri (2004) postulate that governments and private enterprises in developing countries are doing their best to support manufacturing companies, but economic forces such as inflation, interest and exchange rates, which cannot be easily controlled, are curtailing these efforts. Taxation as observed by Mazumdar and Page (1987) discourages most companies from expanding their operations more than larger companies unless special reliefs are given.

Difficulties entering new markets - Singh, Garg, and Deshmukh (2008) argued that on entering new markets, manufacturing companies face many constraints due to lack of resources and poor innovative capabilities. Entering new markets typically requires substantial investment in information gathering. Other barriers to trade often take the form of non-tariff measures (NTMs) like standards or regulations. They can also take the form of lengthy port-handling or custom procedures (ITC, 2014; St-Jean, Julien, \& Audet, 2008; IMF, 2013). St-Jean et al. (2008) also noted that unfair competition from the informal sector, cumbersome regulations, and tax rates are the main obstacles on small businesses from exporting. Bagchi-Sen and Scully (2007) similarly pointed out that innovators performed well in exports and that there were direct links between increased R\&D expenditure and 'innovativeness' in higher levels of export intensity.

\subsection{Competitive Strategy}

According to Michael Porter's competitive strategy theory, generally, companies choose a strategy that brings competitive advantages. These advantages are based on either a lower cost than competitors or a significant difference from the competitors. Competition strategy consists of the following three strategies:

$>$ Cost Leadership Strategy

$>\quad$ Differentiation Strategy and

$>$ Focus Strategy.

Cost Leadership Strategy - This strategy involves the organization aiming to be the lowest cost producer and / or distributor within their industry. The organization aims to drive cost down for all production elements from the sourcing of materials, to labor costs. To achieve cost leadership a business will usually need large scale production so that they can benefit from "economies of scale". Large scale production means that the business will need to appeal to a broad part of the market. For this reason a cost leadership strategy is a broad scope strategy. A cost leadership business can create a competitive advantage:

$\diamond \quad$ by reducing production costs and therefore increasing the amount of profit made on each sale as the business believes that its brand can command a premium price or 
$\diamond \quad$ by reducing production costs and passing on the cost saving to customers in the hope that it will increase sales and market share.

Differentiation Strategy - With a differentiation strategy the business develops product or service features which are different from competitors and appeal to customers including functionality, customer support and product quality. A differentiation strategy is known as a broad scope strategy because the business is hoping that their business differentiation strategy, will appeal to a broad section of the market. New concepts which allow for differentiation can be protected through patents and other intellectual property rights; however patents have a certain life span and organization always face the danger that their idea which gives them a competitive advantage will be copied in one form or another.

Focus (Niche) Strategy - Under a focus strategy a business focuses its effort on one particular segment of the market and aims to become well known for providing products / services for that segment. They form a competitive advantage by catering for the specific needs and wants of their niche market. Once a firm has decided which market segment they will aim their products at, Porter said they have the option to pursue a cost leadership strategy or a differentiation strategy to suit that segment. A focus strategy is known as a narrow scope strategy because the business is focusing on a narrow (specific) segment of the market.

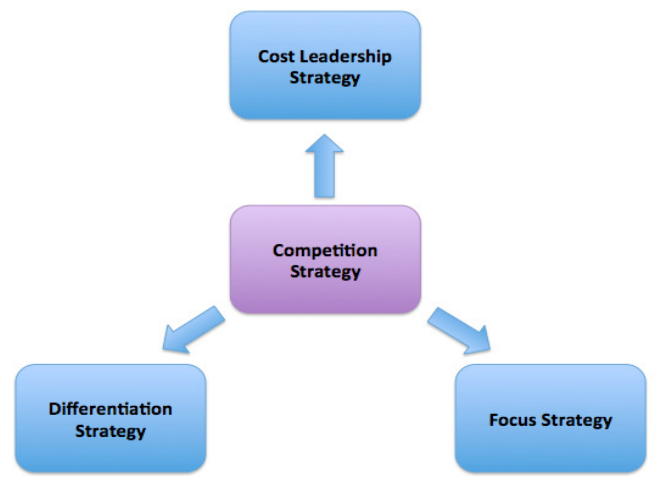

Figure 3. Michael Porter's Competitive Strategy Theory (Porter, M. E. 1998)

Source. CGMA, 2015.

\subsection{Enhancing Industries Competiveness}

McCormick and Maalu (2011) and Chatterjee (2013) observed in their studies that African industries can remain competitive if government empowers them through cluster policies. This comes in the form of creating special economic zones or innovation hubs at strategic locations. This will help enhance competitiveness by providing access to relevant business services to those locating in the cluster. Geographical vicinity itself can facilitate spillovers of innovation across manufacturing companies, thus representing another advantage of clustering (ITC, 2014).

King (2002) cited Swedish Ministry for Foreign Affairs (1997) that for the SME economy to be genuinely capable of contributing to lasting growth in Africa, it must be formalized. Links must be incorporated that are capable of transmitting macroeconomic signals and generating incentives for expansion. Such links may consist of more comprehensive credit systems, reliable regulatory systems and functioning institutions.

The WTO and ITC (2012) looked at supporting such industries through strengthening the delivery of support programs. An often-repeated conclusion of evaluations is the need for more robust results measurement frameworks, the use of impact assessments, and greater attention to baselines and indicators. For example, an evaluation by the Independent Evaluation Group (IEG) of World Bank Group support to SME concluded that the Bank's support "needs to be firmly rooted in a clear, evidence-based understanding of how the proposed support 
Addo, E. O.

will sustainably remove the problems that constrain manufacturing companies' ability to contribute to employment, growth and economic opportunity".

\section{Methods}

This section entails the research design of the study, the research approach, the population and sampling of the study, data collection method and data analysis.

Research Design - Research designs are the plans and procedures for research that span the decisions from broad assumptions to detailed methods of data collection and analysis. This research is a survey, qualitative in nature, and utilizes multiple approaches. Multiple methods have been advocated by scholars to be useful since substantive conclusions can be most confidently derived by triangulating across measures and method reducing the inherent limitation of individual types of research methods (Brewer \& Crano, 2000).

Population - Population refers to the group of interest to the researcher, thus the total number of people to which the outcome of the study is applicable. This research was conducted using all the manufacturing companies in Industrial Area, Accra, estimated to be about 50.

Sampling Size and Sampling Technique - Sampling refers to the process of choosing adequate and representative elements from the population. The convenience sampling, a type of sampling technique, which uses any subject who is available to participate in a research, was employed for the study. 20 companies would be conducted as the sample size drawn from the Industrial Area, Accra.

Data Collection - In collecting data, questionnaires were drafted to reflect the objectives of the study. These were distributed to 20 companies in the target area.

Type of Data - Only qualitative data was used in this study. Qualitative data refers to data which cannot be measured in numbers, like feelings, perception and attitude about a service. The time period in this case is October, 2016.

Source of Data - Though secondary data were reviewed to guide the research design and questionnaires, the main data used was collected from primary source. Primary data involves first hand data collected using questionnaires, observations, and interviews.

Instrument for Data Collection - Questionnaires were used as the main instrument for primary data collection from the respondents. Both opened and closed ended questions were employed in the questionnaires to collect varying data to meet the purpose of the study.

Instruments Validity - Hair (2007) defined the validity as "the degree to which a measure accurately represents what it is supposed to". The researchers ensured that the designed questionnaires measured accurately what it was intended to, based on the objectives of the study. The questionnaires were in plain language for easy understanding. My questionnaires designed were evaluated by my Lecturer to ensure I provided adequate and accurate coverage of the research objectives.

Procedure of Data Collection - The questionnaires were distributed to respondents and feedback was received successfully. Before that, the purpose and the importance of the study were explained to the respondents to stress the significance of the study.

Method of Data Analysis - This section employed the use of descriptive and inference statistics to analyze the main objectives, with the aid of SPSS. Systematically, questionnaires were sorted out for completeness and validity. Accordingly, various questions under each objective were analyzed systematically using the one sample $\mathrm{t}$-test presented in tables and graphs (using Excel). Lastly, logical inferences and interpretations were made out of the resultant data. 


\section{Results}

\subsection{General Information of Sampled Manufacturing Companies}

The manufacturing companies typically employ 30 - 50 workers and managerial positions are on family-related basis (no expertise in the area of operation). The business is mostly set up and controlled by family members over a period of time. In Ghana, Local companies are typically being stifled by stiff competition from foreigners, perverse regulatory climates and poor access to capital. Majority of the company's capital base is generated by themselves with little support from financial institutions.

\subsection{Demographic information}

Figure 3 to 6 below shows information about the respondents' gender, age, education and years of working.

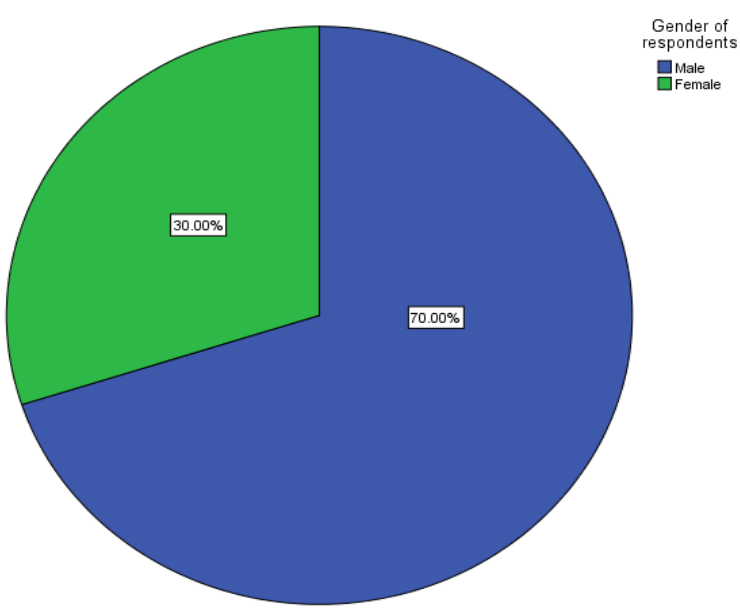

Figure 3. Genders of Respondents

Figure 3 shows that majority of the respondents are Males with $70 \%$ and the minority being Females with 30 $\%$

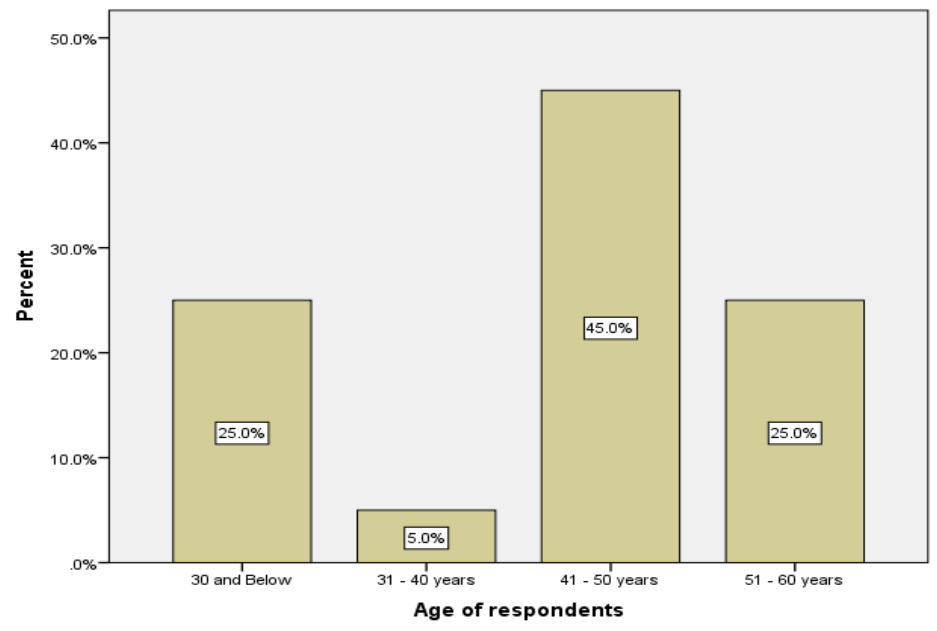

Figure 4. Ages of Respondents 
Addo, E. O.

Figure 4 depicts a little over 5\% of the respondents fall between the 31 - 40 Years age group; $25 \%$ each are both ages 51 - 60 years, and ages 30 years and below respectively. Whiles majority of the respondents (45\%) fall within 41-50 years.

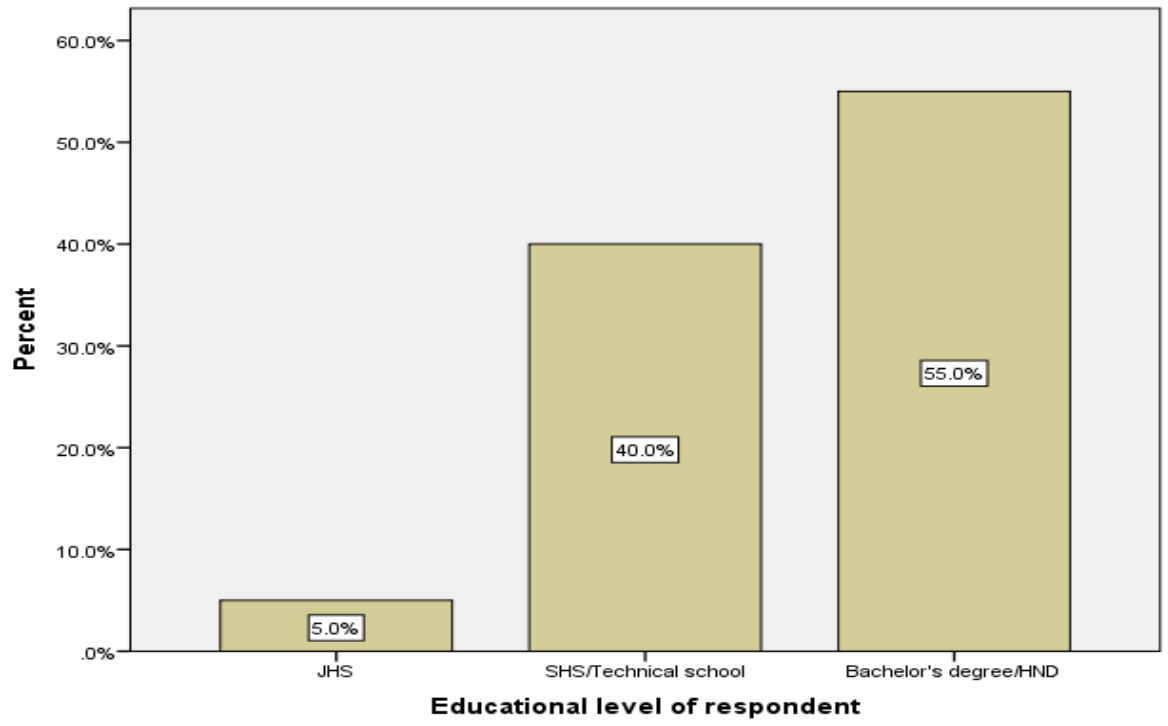

Figure 5 Educational Backgrounds of Respondents

Figure 5 above indicates that 5\%, $40 \%$ and $55 \%$ of the respondents have education, JHS education, Secondary / Tertiary education and Bachelor's degree / HND respectively.

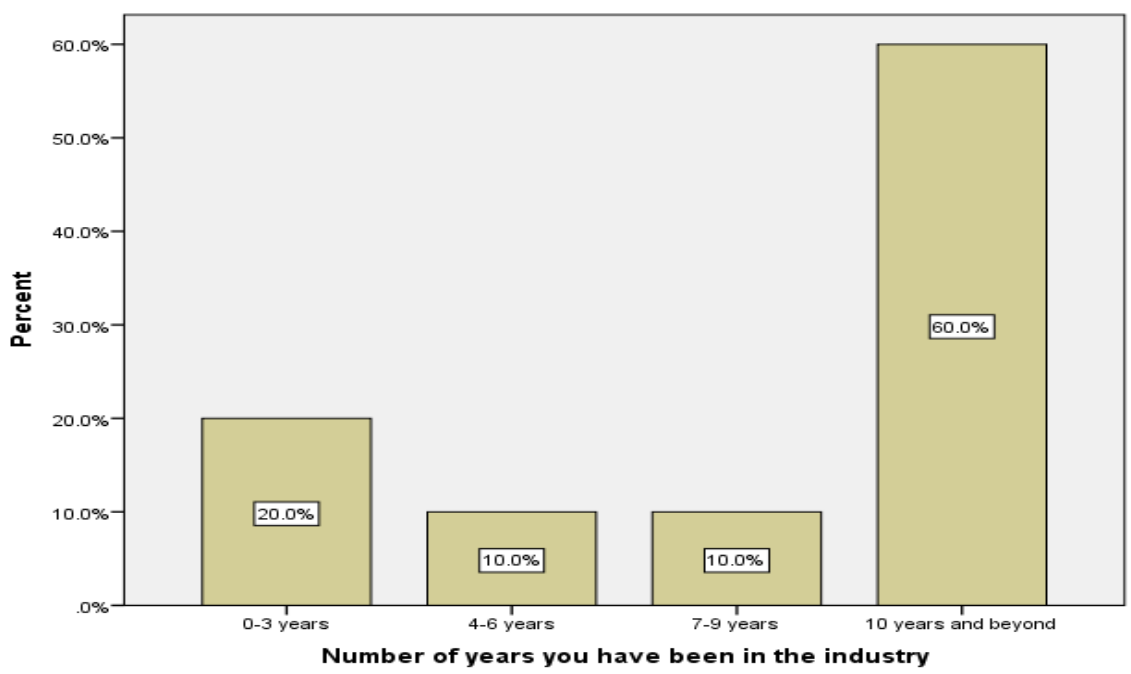

Figure 6 Respondents Years of Working

Figure 6 above shows that $20 \%$ of respondents fall between 0 - 3 working years; $10 \%$ between 4 - 6 working years; $10 \%$ between 7 - 9 working years and the remaining $60 \%$ have 10 years and beyond working experience.

\subsection{One Sample T-Test Analysis of Research Objectives}

The following tables 3 to 4.3 were analyzed with one sample t-test to find the measured variables' means and compare them with test value (set at 4) to draw a conclusion on the study outcome to represent the main population. The $\mathrm{N}$ is the number of respondents; $\mu$ is the mean; standard deviation $(\sigma)$ is the amount of variation among each variable rating; the test results and significance columns shows both the hypothesized results and their level of significance respectively. Table 3 seeks to determine the internal factors affecting the 
competitiveness of manufacturing industries.

Table 3

T-Test Statistics for Internal Factors affecting manufacturing companies Competitiveness

\begin{tabular}{|c|c|c|c|c|c|}
\hline \multirow{2}{*}{ Variable } & \multicolumn{3}{|c|}{ Test Value $(\mathrm{TV})=4$} & \multicolumn{2}{|l|}{$\alpha=0.05$} \\
\hline & $N$ & $\operatorname{Mean}(\mu)$ & $S D$ & Test Result & Sig. \\
\hline 1. Level of Education & 20 & 4.05 & .605 & $\mu>\mathrm{TV}$ & .000 \\
\hline 2. Management Skills & 20 & 4.05 & .510 & $\mu>\mathrm{TV}$ & .000 \\
\hline 3. Capital & 20 & 4.05 & .510 & $\mu>\mathrm{TV}$ & .000 \\
\hline 4. Record keeping & 20 & 4.05 & .503 & $\mu>\mathrm{TV}$ & .000 \\
\hline 5. Sharing of Control & 20 & 4.05 & .410 & $\mu>\mathrm{TV}$ & .000 \\
\hline 6. Marketing Skills & 20 & 4.05 & .444 & $\mu>\mathrm{TV}$ & .000 \\
\hline 7. Technology & 20 & 4.05 & .671 & $\mu>\mathrm{TV}$ & .000 \\
\hline 8. Customer/Supplier Relation & 20 & 4.05 & .444 & $\mu>\mathrm{TV}$ & .000 \\
\hline
\end{tabular}

Source. Field Survey, October 2016.

The "test result" column from table 3 is the hypothesis testing which compares the mean of each variable with the test value (TV), and the significance column measures the level of significance for each t-test. The mean scores of each variable is compared with the test value $(\mathrm{TV}=4)$ to determine whether the manufacturing companies agreed or disagreed with each of the statements making up the "internal factors affecting its competitiveness". Thus the companies are split between "agree" and "disagree", on a five point Likert rating which ranges from Strongly Agree (5) to Strongly Disagree (1). The null and the alternative hypotheses were specified as follow:

Null hypothesis $\mathrm{H}_{0 \mathrm{a}}: \mu \geq 4$ e.g. "Level of Education affects manufacturing companies competitiveness". Alternative hypothesis $\mathrm{H}_{1 \mathrm{a}}: \mu<4$ e.g. "Level of Education does not affect manufacturing companies competitiveness". The hypothesized one sample t-test results from the table shows that all variable's means are significantly greater than the test value (4) at a 95\% confidence level. The variable's means of Level of Education (4.05), "Management Skills" (4.45), "Capital" (4.55) and "Record Keeping" (4.60) are greater than the test value (4). The other variables in Table 4.1 which includes "Sharing of control" (4.20), "Marketing Skills" (4.25), "Technology" (4.35) and "Consumer/Supplier Relation Management" (4.25) all have means greater than the test value (4). Therefore, we fail to reject the null hypotheses of the respective internal factor variables that affect manufacturing companies competiveness, $95 \%$ confidence level (the probability that the results were not due to chance).

Table 4 seeks to determine the external factors affecting the competitiveness of manufacturing industries.

\section{Table 4}

T-Test Statistics for External Factors affecting manufacturing companies Competitiveness

\begin{tabular}{|c|c|c|c|c|c|}
\hline \multirow{2}{*}{ Variable } & \multicolumn{3}{|c|}{ Test Value $(\mathrm{TV})=4$} & \multicolumn{2}{|l|}{$\alpha=0.05$} \\
\hline & $N$ & $\operatorname{Mean}(\mu)$ & $S D$ & Test Result & Sig. \\
\hline 9. Access to Risk Capital & 20 & 4.05 & .444 & $\mu>\mathrm{TV}$ & .000 \\
\hline 10. Unfavorable Competition & 20 & 4.05 & .571 & $\mu>\mathrm{TV}$ & .000 \\
\hline 11. Borrowing & 20 & 4.05 & .503 & $\mu>\mathrm{TV}$ & .000 \\
\hline 12. Rent Cost & 20 & 4.05 & .444 & $\mu>\mathrm{TV}$ & .000 \\
\hline 13. Electricity Supply & 20 & 4.05 & .410 & $\mu>\mathrm{TV}$ & .000 \\
\hline $\begin{array}{l}\text { 14. Poor regulatory environment } \\
\text { 15. Environmental dynamism }\end{array}$ & 20 & 4.05 & .826 & $\mu>\mathrm{TV}$ & .000 \\
\hline
\end{tabular}

Source. Field Survey, October 2016.

In Table 4 above, the mean scores of each variable is compared with the test value $(\mathrm{TV}=4)$ to determine whether the said companies agreed or disagreed with each of the statements making up the "external factors affecting its competitiveness". Thus the manufacturing companies are split between "agree" and "disagree", 
Addo, E. O.

from a five point Likert rating which ranges from Strongly Agree (5) to Strongly Disagree (1). Each of the variable null and the alternative hypotheses, for example, were formulated as follows:

Null hypothesis $\mathrm{H}_{0 \mathrm{~b}}: \mu \geq 4$ "Access to Risk Capital affects manufacturing companies competitiveness". Alternative hypothesis $\mathrm{H}_{1 \mathrm{~b}}: \mu<4$ "Access to Risk Capital does not affect manufacturing companies competitiveness".

The results from the hypotheses testing summarized in the "Test Result" column shows that all the variable means are greater that the test value (4), including Access to Risk Capital (4. 25), Foreign Competition (4.30), Borrowing Cost (4.60) Rent cost (4.25). The others are Electricity Supply (4.80), Poor regulatory environment (4.05) and Environmental dynamism (4.05). All the results were also significant at $95 \%$ confidence level. Therefore, we fail to reject any of the null hypotheses that any of the external factor variables affect manufacturing companies competitiveness. This means that manufacturing industries believe that the variables in Table 5 are all external factors that affect its competiveness.

Table 5 seeks to ascertain the competitive strategies of manufacturing industries.

Table 5

T-Test Statistics for Competitive Strategies adopted by manufacturing companies

\begin{tabular}{|c|c|c|c|c|c|}
\hline \multirow{2}{*}{ Variable } & \multicolumn{3}{|c|}{ Test Value $(\mathrm{TV})=4$} & \multicolumn{2}{|l|}{$\alpha=0.05$} \\
\hline & $N$ & $\operatorname{Mean}(\mu)$ & $S D$ & Test Result & Sig. \\
\hline 16. Cost Strategy & 20 & 4.25 & .786 & $\mu>\mathrm{TV}$ & .000 \\
\hline 17. Differentiation & 20 & 4.02 & .649 & $\mu>\mathrm{TV}$ & .000 \\
\hline 18. Innovation & 20 & 4.20 & .616 & $\mu>\mathrm{TV}$ & .000 \\
\hline $\begin{array}{l}\text { 19. Able to meet market } \\
\text { demand }\end{array}$ & 20 & 4.45 & .510 & $\mu>\mathrm{TV}$ & .000 \\
\hline 20. Relationship Competence & 20 & 4.30 & .571 & $\mu>\mathrm{TV}$ & .000 \\
\hline $\begin{array}{l}\text { 21. Ability to gain value for } \\
\text { money }\end{array}$ & 20 & 4.55 & .510 & $\mu>\mathrm{TV}$ & .000 \\
\hline
\end{tabular}

Table 5 measures the responses from manufacturing companies to determines the strategies they deploy to remain competitive. The mean scores of each variable is compared with the test value $(\mathrm{TV}=4)$ to determine whether the companies agreed or disagreed with each of the statements making up the "its competitive strategy". The manufacturing companies are split between "agree" and "disagree", from a five point Likert rating which ranges from Strongly Agree (5) to Strongly Disagree (1).

For example, each of the variable's null and alternative hypotheses was formulated as follows:

Null hypothesis $\mathrm{H}_{0 \mathrm{c}}: \mu \geq 4$ "Cost Strategy is a manufacturing companies competitiveness strategy". Alternative hypothesis $\mathrm{H}_{1 \mathrm{c}}: \mu<4$ "Cost Strategy is not a manufacturing companies competitiveness strategy". The hypothesized one sample t-test results from the table shows that all the variable's means are significantly greater than the test value (4) namely, Cost Strategy (4.25), Differentiation (4.02), Innovation (4.20) and Ability to Meet Market Demand (4.45). The remaining is Relationship Competence (4.30) and the Ability to Gain Value for Money (4.55).

For that matter we fail to reject any of the null hypotheses that the strategies determined in Table 3 are manufacturing companies' competitive strategies. This means that the above strategies mentioned in Table 5 are strategies used by companies in the industry.

Table 6 seeks to explore ways of enhancing the competitiveness of manufacturing industries. 
The impact of manufacturing industries on Ghana's economy

Table 6

T-Test Statistics for ways of enhancing the competitiveness of manufacturing companies

\begin{tabular}{lccccc}
\hline \multicolumn{1}{c}{ Variable } & \multicolumn{4}{c}{ Test Value $(\mathrm{TV})=4$} & $\alpha=0.05$ \\
\cline { 2 - 6 } & $N$ & Mean $(\mu)$ & .510 & $\mu>$ Test Result & Sig. \\
\hline 22. Level play field & 20 & 4.55 & .671 & $\mu>$ TV & .000 \\
23. Target Program & 20 & 4.15 & .510 & $\mu>$ TV & .000 \\
24. Tolerating Risk & 20 & 4.45 & .550 & $\mu>$ TV & .000 \\
25. Innovation & 20 & 4.25 & .553 & $\mu>$ TV & .000 \\
26. Technology Adoption & 20 & 4.10 & .489 & $\mu>$ TV & .000 \\
27. New Marketing Ways & 20 & 4.15 & .553 & $\mu>$ TV & .000 \\
28. Strategic skills & 20 & 4.10 & .470 & $\mu>$ TV & .000 \\
29. Effective Succession Plan & 20 & 4.30 & & &
\end{tabular}

Source. Field Survey, October 2016.

Table 6 measures the responses of manufacturing companies to determine how to enhancing their competitiveness. The mean scores of each variable is compared with the test value $(\mathrm{TV}=4)$ to determine whether manufacturing companies agreed or disagreed with each of the statement making up the "Ways of enhancing its competitiveness".

The mean scores of each variable is compared with the test value $(\mathrm{TV}=4)$ to determine whether the manufacturing companies agreed or disagreed with each of the statements making up the "Ways of enhancing its competitiveness". The manufacturing companies are split between "agree" and "disagree", from a five point Likert rating which ranges from Strongly Agree (5) to Strongly Disagree (1).

For example, each of the variable null and the alternative hypotheses were formulated as follows:

Null hypothesis $\mathrm{H}_{0 \mathrm{~d}}: \mu \geq 4$ "Creating a leveled playing field is a way of enhancing manufacturing companies Competitiveness". Alternative hypothesis $\mathrm{H}_{1 \mathrm{~d}}: \mu<4$ "Creating a leveled playing field is not a way of enhancing manufacturing companies Competitiveness". The statistics shows that all the means of the variables are greater than the test value (4) as displayed in the "Test Result" column as a summary of the hypotheses testing. This includes Leveled Play Field (4.55), Target Programs (4.15), Tolerating Risk (4.45) and Innovation (4.25). Other variable's means, greater than the test value, are Technology Adoption (4.10), New Marketing Ways (4.15), Strategic Skills (4.10) and Effectives Succession Plan (4.30). Therefore, at 95\% confidence level, we fail to reject any of the null hypotheses that the variables in Table 6 are ways of enhancing manufacturing companies Competitiveness.

\section{Discussions of Findings}

\subsection{Internal Factors that affect Manufacturing Industries}

The results reveal that respondents believe all the variables in Table 2 are internal factors that affect its competitiveness. The findings of Management Skills linked with the level of owners' education alongside Capital suggest the reasons why most local companies hardly meet its contribution (quotas) to Ghana's economy.

\subsection{External Factors that affect Manufacturing industries}

The t-test results show that all the variables in Table 3 are factors affecting its competitiveness. In general the infrastructure problem in most African countries forestalls industrial growth as observed by Ukpong and Iniodu (1991) and Awura (2006). Unfavorable tax system, Electricity Power supply and the inability of companies to meet consumer preference in Ghana have also been a major problem contributing to its failure. 
Addo, E. O.

\subsection{Competitive Strategies adopted by Local Manufacturers}

All the variables in Table 4 were identified by sector companies as the competitive strategies deployed in their daily operations. This shows that no single organization adopt a single strategy if it really want to remain competitive in this highly dynamic market with a relatively low barrier to entrants.

\subsection{Ways of Enhancing the Industry Competitiveness.}

The finding shows that manufacturing companies agreed to all the measures suggested in Table 5 to enhance their competitiveness. This finding corroborates the views of Osamwonyi and Tafamel (2010) in their recommendations of ways to sustain Nigerian local enterprises. Companies need to enhance their competitiveness probably due to the threat and opportunities created by technological advancement. Though the majority of ways of enhancing competitiveness depends on government policies, Local Manufacturing Companies need to do a lot of homework as far as Operations is concern.

\section{Summary, conclusion, and recommendations}

\subsection{Summary}

This research sought, in other ways, to examine the factors that influence manufacturing companies competitiveness, highlighting both the internal and external factors, competitive strategies deployed and measures to improve its competitiveness. The sample size of the study is 20 manufacturing companies, with a response rate of $90 \%$ from 20 questionnaires distributed at Industrial Area, Accra. The Likert type questionnaires were used to collect the data through convenience sampling technique in a survey study which is qualitative in nature. The data were analysed quantitatively using one sample t-test with the aid of SPSS and Excel.

The following were the main findings of the study.

$>$ The internal factors affecting local manufacturing companies competitiveness are Management Skills, Capital, Level of Education and External Relation Management among other.

$>$ Also the main external factors' influencing its competitiveness includes, Electricity Supply, Tax System, Rent cost, Consumer Preference and Competition from Foreign Traders.

D Again the main strategies deployed by manufacturing companies to remain competitive are Relationship Skills, Innovation, Differentiation and the Ability to Meet Market Demands in that order.

$>$ Lastly creation of equal playing field, new marketing techniques, strategic management competence and good succession plan are the ways to enhance its competitiveness.

\subsection{Conclusion}

The findings show that both internal and external factors influence the competitiveness of manufacturing companies through the deployment of a combination of strategies. All the main variables from both the internal and external factors were highly rated by respondents. Other important measures like creating equal playing fields for its survival were noted. The implication of the findings is that manufacturing companies need to acquire the basic business skills to be able to grow and sustain their business. This is because education is linked with many of the internal and external factors and strategies affecting its competitiveness, for example management skills, marketing skills, and meeting market demands. The implication of this research for government is that it needs to do the major work by creating an enabling environment, e.g. flexible tax regime, to benefit from manufacturing industries as the engine of growth in the economy. 


\subsection{Recommendations}

The research revealed some challenges affecting manufacturing companies' competitiveness. Below are some suggestions:

$>\quad$ The government should create enabling business environments which will foster its growth and sustainability, through the provision of basic infrastructure, flexible tax system, formidable legal and regulatory environment etc.

$>\quad$ The government should develop programs targeted at such companies which will have the great impact on society in terms of job creation, poverty alleviation etc.

$>\quad$ Owner-managers should update their skills regularly to keep abreast with new ways of marketing to meet the ever changing consumer preferences and market dynamics.

$>\quad$ Owner-managers should bring on board people with the necessary skills to expand the business into new markets, then relying on family members.

$>$ Owner-managers should acquire strategic management skills needed to conduct effective market analysis to remain competitive.

Acknowledgements: For HIS merciful kindness is great toward me and the truth of the Lord endureth forever. Without HIS endless mercy and care, I would not have achieved what I am today. My sincere thanks and appreciation goes to the Ghana Statistical Service, together with the Bank of Ghana, The World Bank and the Ministry of Trade and Industry - Ghana, for their joint efforts in making available data for this research. Finally, I wish to thank my entire family for their support and encouragement in producing this paper.

\section{References}

Abor, J., \& Quartey, P. (2010). Issues in SME development in Ghana and South Africa. International Research Journal of Finance and Economics, 39(6), 215-228.

Ackah, C., Turkson, F. E., \& Opoku, K. (2013). Measuring trade costs in Economic Community of West African States (ECOWAS). Modern Economy, 4(1), 56. https://doi.org/10.4236/me.2013.41007

Ajitabh, A., \& Momaya, K. S. (2003). Competitiveness of firms: Review of theory, frameworks and models. Singapore Management Review, 26(1), 45-61.

Anaman, K. A., \& Osei-Amponsah, C. (2009). Determinants of the output of the manufacturing industry in Ghana from 1974 to 2006. Retrieved from https://www.africaportal.org/publications/determinants-of-the-output-of-the-manufacturing-industry-inghana-from-1974-to-2006/

Aryeetey, E., \& Moyo, N. (2011). The global food and financial crises and the poor in Africa. The food and financial crises in Sub-Saharan Africa: Origins, impacts and policy implications, 22.

Bagchi-Sen, S., \& Scully, J. (2007). Strategies and external relationships of small and medium-sized enterprises in the US agricultural biotechnology sector. Environment and Planning C: Government and Policy, 25(6), 844-860. https://doi.org/10.1068/c0560

Bartlesman, E., \& Gray, W. B. (1996). The NBER manufacturing productivity database.

Batra, G., \& Tan, H. (2003). SME technical efficiency and its correlates: Cross-national evidence and policy implications. World Bank Institute Working Paper, 9.

Beck, T., Demirguc-Kunt, A., \& Levine, R. (2003). Bank supervision and corporate finance (No. w9620). National Bureau of Economic Research. https://doi.org/10.3386/w9620

Bleda, M., Morrison, K., \& Rigby, J. (2013). The role and importance of gazelles and other growth firms for innovation and competitiveness. In D. Cox \& J. Rigby (Eds.), Innovation policy challenges for the 21 st 
century (pp. 36-63). London: Routledge.

Bokea, C., Dondo, A., \& Mutiso, J. (1999). Physical infrastructure. In the Micro and small enterprises in Kenya: Agenda for improving the policy environment (pp. 57-80). Nairobi: International Centre for Economic Growth,.

Bouazza, A. B. (2015). Small and medium enterprises as an effective sector for economic development and employment creation in Algeria. International Journal of Economics, Commerce and Management, 3(2), 1-16.

Brewer, M. B., \& Crano, W. D. (2000). Research design and issues of validity. In H. T. Reis \& C. M. Judd (Eds.), Handbook of research methods in social and personality psychology (pp. 3-16). New York: Cambridge University Press.

Chatterjee, D., Grewal, R., \&Sambamurthy, V. (2002). Shaping up for e-commerce: institutional enablers of the organizational assimilation of web technologies. MIS quarterly, 26(2), 65-89.

Chatterjee, S. (2013). Simple rules for designing business models. California Management Review, 55(2), 97-124.

Cheah, C. Y., \& Chew, D.A. (2005). Dynamics of strategic management in the Chinese construction industry. Management Decision, 43(4), 551-567.

Chew, D. A., Yan, S., \& Cheah, C. Y. (2008). Core capability and competitive strategy for construction SMEs in China. Chinese Management Studies, 2(3), 203-214.

Chiloane-Tsoka, E., \& Boya, K. S. (2014). An Exploration of strategic competitiveness of SMMEs: A South African perspective. Problem and Perspectives in Management, 12(4), 347-354.

Essegbey, G. O., \& Frempong, G. K. (2011). Creating space for innovation- The case of mobile telephony in MSEs in Ghana. Technovation, 31(12), 679-688.

Ghana News Agency [GNA]. (2015). Retrieved from http://www.graphiconline.com

Hair, J. F. (2007). Research methods for business. Hoboken, NJ: John Wiley \& Sons.

Harvie, C., \& Lee, B. C. (2005). Public policy and SME development. In C. Harvie \& B.-C. Lee (Eds.), Sustaining growth and performance in East Asia: The role of small and medium sized enterprises. Edward Elgar Publishing. http://dx.doi.org/10.4337/9781845425630.00024

Harvie, C., \& Lee, B. C. (Eds.). (2005). Sustaining growth and performance in East Asia: The role of small and medium sized enterprises (Vol. 3). Edward Elgar Publishing. http://dx.doi.org/10.4337/9781845425630

Hewitt, T., \& Wield, D. (1992). Industrialization and development. Oxford University Press.

Hewitt-Dundas, N. (2006). Resource and capability constraints to innovation in small and large plants. Small Business Economics, 26(3), 257-277. https://doi.org/10.1007/s11187-005-2140-3

Holt, D. H. (1992). Entrepreneurship: New venture creation. Prentice Hall.

Hultén, P. (2009). Swedish SMEs' establishment of business in Russia: A case study. Journal of East-West Business, 15(1), 5-24. https://doi.org/10.1080/10669860902900206

Iniodu, P. U. (1991). Smallholder credit for agricultural development: A model for Akwa Ibom State. Ukpong, II and Iniodu, edts., Priorities for the Development of Akwa Ibom State. Center for Development Studies, Uyo, 15 .

International Finance Corporation [IFC]. (2010). Annual report. Washington, DC: Author.

Jansen, M., \& Lanz, R. (2013). Skills and export competitiveness for small and medium-sized enterprises. World Trade Organization, Geneva.

King, K., \& McGrath, S. (2002). Globalisation, enterprise and knowledge: Education, training and development in Africa. Symposium Books Ltd. https://doi.org/10.15730/books.33

Li, X., Hitt, L. M., \& Zhang, Z. J. (2011). Product reviews and competition in markets for repeat purchase products. Journal of Management Information Systems, 27(4), 9-42. https://doi.org/10.2753/MIS0742-1222270401

Liedholm, C., McPherson, M., \& Chuta, E. (1994). Small enterprise employment growth in rural Africa. American Journal of Agricultural Economics, 76(5), 1177-1182. https://doi.org/10.2307/1243413

Little, I. M., Page, J. M., \& Mazumdar, D. (1987). Small Manufacturing Enterprises. New York: Oxford University Press. 
The impact of manufacturing industries on Ghana's economy

Lussier, R. N., \& Pfeifer, S. (2001). A cross-national prediction model for business success. Journal of Small Business Management, 39(3), 228-239. https://doi.org/10.1111/0447-2778.00021

Man, T. W., Lau, T., \& Chan, K. F. (2002). The competitiveness of small and medium enterprises: A conceptualization with focus on entrepreneurial competencies. Journal of business venturing, 17(2), 123-142. https://doi.org/10.1016/S0883-9026(00)00058-6

Matlay, H., \& Fletcher, D. (2000). Globalization and strategic change: some lessons from the UK small business sector. Strategic Change, 9(7), 437. https://doi.org/10.1002/1099-1697(200011)9:7<437::AID-JSC517>3.0.CO;2-Y

McCormick, D., \& Maalu, J. (2011). Innovation hubs and small and medium enterprises. Africa Setting the Policy Agenda.

Meng, S. M., Liang, G. S., \& Yang, S. H. (2011). The relationships of cruise image, perceived value, satisfaction, and post-purchase behavioral intention on Taiwanese tourists. African Journal of Business Management, 5(1), 19-29.

Mensah, S. (2004, March). A review of SME financing schemes in Ghana. In A Presentation at the UNIDO Regional Workshop of Financing SMEs (pp. 15-16). Ghana: Accra.

Minniti, M., \& Bygrave, W. (2003). Global entrepreneurship monitor: national entrepreneurship assessment. United States of America.

Morrison, A. (2006). A contextualisation of entrepreneurship. International Journal of Entrepreneurial Behavior\& Research, 12(4), 192-209. https://doi.org/10.1108/13552550610679159

National Accounts Statistics [NAS]. (2014). Ghana statistical service.

Nzelibe, C. G. O. (1996). Entrepreneurship and management of small scale business. Enugu: Optimal Pub.

OECD. (2000). Enhancing the competitiveness of SMEs in the global economy: Strategies and policies, conference for ministers responsible for SMEs and industry ministers. Bologna, Italy.

Ojiako, U. (2012). Examining thematic elements in strategic business risk. Management Research Review, 35(2), 90-105. https://doi.org/10.1108/01409171211195134

Osamwonyi, I. O., \& Tafamel, A. E. (2010). Options for sustaining small and medium scale enterprises in Nigeria: Emphasis on Edo state. African Research Review, 4(3). https://doi.org/10.4314/afrrev.v4i3.60249

Perry, C., \& Pendleton, W. (1983). Successful small business management. Pitman.

Porter, M. E. (1980). Industry structure and competitive strategy: Keys to profitability. Financial Analysts Journal, 36(4), 30-41. https://doi.org/10.2469/faj.v36.n4.30

Porter, M. E. (1985). Competitive advantage. New York.

Porter, M. E. (1985). Technology and competitive advantage. Journal of business strategy, 5(3), 60-78. https://doi.org/10.1108/eb039075

Quartey, P., \& Kayanula, D. (2000). The policy environment for promoting small-scale and medium-sized enterprises in Ghana and Malawi. Finance and Development Research Programme, Working Paper Series, 15.

Ross, J., \& Staw, B. M. (1991). Managing escalation processes in organizations. Journal of Managerial Issues, 3 , 15-30.

Singh, R. K., Garg, S. K., \& Deshmukh, S. G. (2008). Strategy development by SMEs for competitiveness: a review. Benchmarking: An International Journal, 15(5), 525-547. https://doi.org/10.1108/14635770810903132

Stigler, J (1991). Individuals, institutions and academic achievement. Social theory for a changing society.

St-Jean, E., Julien, P. A., \& Audet, J. (2008). Factors associated with growth changes in Gazelles. Journal of Enterprising Culture, 16(2), 161-188. https://doi.org/10.1142/S0218495808000089

Temtime, Z. T., \& Pansiri, J. (2004). Small business critical success/failure factors in developing countries: some evidences from Botswana.

United Nations Development Program [UNDP]. (2012) Report. Author.

Visser, E. J. (1999). A comparison of clustered and dispersed firms in the small-scale clothing industry of Lima. World Development, 27(9), 1553-1570. https://doi.org/10.1016/S0305-750X(99)00077-7 
Addo, E. O.

Weber, A. (1909). Theory of industrial location.

World Trade Organization. (2012). Annual report. Washington DC: Author. 